\title{
Refugiado, cidadão universal: uma análise do direito à identidade pessoal*
}

\section{Refugee, universal citzen: an análisys of the right to a personal identity}

Patrícia Magno

\section{Resumo}

Utilizando-se dos marcos legislativos brasileiros consubstanciados na Constituição Federal de 1988 e na Lei 9437/97, assim como sua interlocução com o Direito Internacional dos Direitos Humanos, com o Direito Internacional Humanitário e com o Direito Internacional dos Refugiados, enquanto vertentes de proteção da pessoa humana refugiada, este estudo trata o refugiado como titular do direito humano universal de receber asilo, para demonstrar que o exercício da cidadania universal plena depende diretamente da efetividade do direito à identidade pessoal e é dever do Estado de acolhida.

Palavras-chave: Direito Internacional dos Refugiados. Direito à identidade. Direitos Humanos. Dever do Estado de acolhida.

\begin{abstract}
Using the Brazilian legislative marks in the Federal Constitution of 1988 and in the Law 9437/97, as well as its interchange with International Law of Human Rights with Humanitarian International Law and the Refugees' International Law, while approaching the protection of the displaced human right, this study refers the refugeed person as holder of the universal human right to grant political asylum, to demonstrate that the exercise of the absolute universal citizenship depends directly on the effectiveness of the right to a personal identity and it is a duty of the Reception State.
\end{abstract}

Keywords: Refugees' International Law. Right to a personal identity. Human Rights. Duty of the reception State.

\footnotetext{
* Recebido em 04.04.11 Aprovado em 28.09.11

1 Defensora Pública do Estado do Rio de Janeiro, Mestre pela Universidade do Estado do Rio de Janeiro, pós-graduada em Direitos Humanos pelo Centro de Derechos Humanos de la Faculdad de Derecho de la Universidad de Chile. E-mail: patymagno@gmail.com
} 


\section{Introdução}

Este estudo situa-se na encruzilhada entre paradigmas da soberania nacional e dos direitos humanos, sendo o refugiado seu representante (MELO, 2001, p. 268), uma vez que, da sua condição de ser humano, decorrem direitos exigíveis de um Estado do qual não é nacional.

A partir do diálogo entre o Direito Internacional dos Direitos Humanos (DIDH), o Direito Internacional Humanitário (DIH) e o Direito Internacional dos Refugiados (DIR), situa-se a temática do refúgio no terceiro milênio e se estabelecem as bases para a construção do conceito de cidadania universal. Da convergência dessas três vertentes de proteção da pessoa humana refugiada, constrói-se o alicerce do dever jurídico do Estado de acolhida em reconhecer o status de refugiado.

Analisa-se a normativa referente à documentação do refugiado, uma vez que o direito à identidade é direito humano universal. Demonstra-se, por fim, que o exercício da cidadania universal plena depende diretamente da efetividade do direito à identidade pessoal, que retira o refugiado da invisibilidade e lhe assegura os meios para o exercício dos direitos inerentes à vida civil.

\section{Refúgio no terceiro milênio}

O século XXI foi inaugurado sem que se expurgasse do cenário internacional a necessidade de alguns indivíduos buscarem refúgio. Refugiar-se é buscar proteção e segurança, ou condições de concretizar os direitos fundamentais. Significa, ainda, recomeçar, construir novos projetos de vida e, sobretudo, salvar a própria vida, em condições de dignidade e de respeito (MILESI, 2008). O drama dos refugiados e das refugiadas é, sem dúvida, um dos desafios mais urgentes da conjuntura internacional ${ }^{2}$.

\footnotetext{
2 No Brasil existem, atualmente, segundo o CONARE (Comitê Nacional para os Refugiados, órgão colegiado vinculado ao Ministério da Justiça, criado pela Lei 9474/97), cerca de 3.400 (três mil e quatrocentos) refugiados reconhecidos, de 69 nacionalidades diferentes, a maior parte $(78 \%)$ do continente africano (MILESI; LACERDA, 2007. p. 20), sendo certo que, aproximadamente, 95\% dos refugiados residem no eixo Rio-São Paulo.
}

O refugiado ${ }^{3}$ é um estrangeiro em situação de risco, que deixou seu país por motivo de bem-fundado temor de perseguição em função de sua raça, religião, nacionalidade, opinião política ou pertencimento a um grupo social ${ }^{4}$, ou devido à situação local de maciça e grave violação de direitos humanos ${ }^{5}$. Em situação análoga à do refugiado, encontra-se $\mathrm{o}$ asilado, aquele estrangeiro que obtém o asilo no país de acolhida, em virtude de perseguição causada por suas opiniões políticas no país de origem ${ }^{6}$.

O fenômeno migratório contemporâneo, dentro do qual se insere o refúgio - enquanto espécie de migração forçada ${ }^{7}$ - por sua intensidade e diversificação, torna-

3 Ensina José H Fischel de Andrade que: "No plano jurídicoconceitual, pôde-se testemunhar uma gradativa escolha por se definir o termo 'refugiado' em uma perspectiva individualista, i.e., tomando como indivíduo, e não em razão do grupo ao qual ele pertencesse. [...] Contudo, a dinâmica das relações internacionais contemporâneas tem provado que a flexibilidade, no que respeita às soluções vislumbradas para os refugiados, faz-se sempre mister e constitui-se em penhor de sucesso em negociações tais, cujo "objeto" de transação é o homem em sua aventura vital” (ANDRADE, 1996, p. 183).

4 Conforme o conceito universal presente na Convenção Relativa ao Estatuto dos Refugiados (Convenção de 1951).

$5 \mathrm{O}$ conceito de violência generalizada, invasão estrangeira e conflito interno como razões para a caracterização do refúgio foram introduzidos pela a Declaração de Cartagena, em 1984, década em que a América Latina e Central eram palco de muitos conflitos. Muitos países vivenciaram árduas lutas contra sanguinolentos golpes militares pela construção da democracia. Líderes políticos tiveram que se abrigar e se exilar em países vizinhos ou distantes até que a situação política no seu país se normalizasse. A Declaração de Cartagena se tornou um ponto de referência que proporcionou um enfoque inovador para a proteção e soluções para os refugiados. Assim, por essa Declaração, todas as pessoas, cuja necessidade de proteção seja evidente, devem passar a ser protegidas e assistidas. (MILESI; LACERDA, 2007, p. 36-37).

6 A definição de Celso D. de Albuquerque Mello indica que refugiados são "[...] as pessoas que gozam de asilo territorial. A Convenção de 1951, que estabeleceu o estatuto dos refugiados, define-os" (MELLO, 2004, p. 1093). Pode-se acrescentar - indica o saudoso mestre - "[...] que no continente americano o conceito de refugiado é mais amplo do que o de asilado territorial. Assim sendo, todo asilado territorial é refugiado, mas nem todo refugiado é asilado territorial", guardando uma relação de gênero e espécie. Asilo é gênero, do qual são espécies: o asilo diplomático ou asilo em sentido estrito e o asilo territorial ou refúgio (2004, p. 1095). No mesmo sentido, vide Jubilut (2007, p.49). A autora apresenta excelente quadro comparativo entre as duas espécies de asilo, sob o enfoque do ordenamento jurídico brasileiro.

7 No mesmo sentido é a lição de Luis Varese que coloca o refúgio no marco da migração forçada. Ensina o autor que, "[...] historicamente, a migração forçada mais terrível foi a escravidão. Lamentavelmente, isso continua sendo. Mas os fatores predominantes são as guerras, a fome e os desastres naturais" (VARESE, 2006, p. 7-12). 
se, cada vez mais complexo, principalmente no que se refere às causas que o originam. Entre elas, Rosita Milesi destaca:

[...] transformações ocasionadas pela economia globalizada, as quais levam à exclusão crescente dos povos, países e regiões e sua luta pela sobrevivência; a mudança demográfica em curso nos países de primeira industrialização; o aumento das desigualdades entre Norte e Sul no mundo; a existência de barreiras protecionistas que não permitem aos países emergentes colocarem os próprios produtos em condições competitivas nos mercados; a proliferação dos conflitos e das guerras; o terrorismo; os movimentos marcados por questões étnico-religiosas; a urbanização acelerada; a busca de novas condições de vida nos países centrais, por trabalhadores da África, Ásia e América Latina; questões ligadas ao narcotráfico, à violência e ao crime organizado; os movimentos vinculados às safras agrícolas, aos grandes projetos da construção civil e aos serviços em geral; às catástrofes naturais e situações ambientais (MARINUCCI; MILESI, 2006, p. 64).

O adensamento dos fluxos de refugiados é acompanhado pelo aumento da imigração, que não se dá pela flexibilização dos controles migratórios, mas pela pressão por emprego resultante das desigualdades entre os Estados, reforçada pela própria globalização ${ }^{8}$. Esta, norteada pela lógica do neoliberalismo, estabelece um "duplo regime de circulação", que abre as fronteiras para mercadorias

8 Cf. Featherstone (1995). Este autor entende ser a globalização mais que fenômeno de índole econômica, por ser voltado também à integração e homogeneização culturais. Nesse sentido, ela cria um modelo único e é excludente daqueles que nele não se inserem. Segundo o autor, é possível falar em cultura global em sentido diverso da cultura decorrente dos "intensos fluxos internacionais de dinheiro, bens, pessoas, imagens e informação", que "têm dado origem às "terceiras culturas" transacionais". A cultura global aponta para um plano além daquele de trocas entre os Estados, pois o mundo se torna unido à medida que é visto como um único lugar. Nesse contexto, a pessoa humana, na tentativa de resgate e afirmação de sua personalidade, perde-se no tecido social, de alcance profundo e invisível. Configura-se, então, o paradoxo do nosso tempo: a globalização, que é despersonalizadora, versus a proteção do indivíduo, que é essencialmente valorizadora do ser humano. Buscando a causa desse choque, Erik Jayme assevera: "Em verdade, a globalização é caracterizada pelo fato dos Estados não serem mais os centros do poder e da proteção da pessoa humana. Os Estados estão cedendo grande parte de seus poderes aos mercados. A existência de um mercado global permite fusões de grandes empresas, resultando em um poder econômico gigantesco, que deixa aberta a questão da proteção do indivíduo [...]. Os juristas combatem as práticas através dos instrumentos clássicos da responsabilidade civil delitual, enquanto os malfeitores escapam a todos os controles e se protegem em um espaço virtual." (JAYME, 2003, p. 86). e capitais e, simultaneamente, inibe a mobilidade humana (MILESI; LACERDA, 2007, p. 13) ${ }^{9}$.

Os migrantes (gênero no qual se inserem os refugiados) revelam a dimensão negativa do celebrado processo de globalização. São denúncias vivas da desigualdade e tornam-se, na já referida expressão de Carolina Campos Melo, “[...] a representação de uma encruzilhada entre a soberania dos Estados-Nação e a proteção dos direitos humanos.”

Por um lado, na tradicional perspectiva do Direito Internacional, todo Estado tem o direito de manter controle sobre suas fronteiras e determinar as condições de entrada e permanência em seu território, como expressão clássica da soberania nacional. Ao mesmo tempo, a opinião pública mundial e o avanço da proteção aos direitos humanos são fatores que impõem uma releitura da soberania, no sentido de redimensionar o direito de asilo em sentido amplo, em razão de uma maior proximidade entre os direitos humanos, o direito dos refugiados e o direito humanitário, como direito humano dotado de exigibilidade frente ao Estado de acolhida (TRINDADE, 2003, p. 398) $)^{10}$.

9 Haveria, portanto, “[...] uma migração seletiva, que incentiva a entrada de migrantes super-qualificados e fecha as portas para os demais também atraídos pelas promessas de realização. A perda de pessoal qualificado para outros países é um sério desafio aos países em desenvolvimento. [...] O fenômeno migratório atual alcança uma dimensão global, estando essencialmente relacionado à crise do sistema capitalista, incapaz de promover nas periferias o mesmo padrão de vida e consumo dos países desenvolvidos."

${ }^{10} \mathrm{O}$ encontro entre direitos humanos e refúgio realiza-se em pelo menos quatro momentos sucessivos, já que os direitos humanos dos refugiados devem ser respeitados antes, durante e depois do processo de solicitação do asilo. Os direitos humanos devem aqui ser tomados em sua totalidade (inclusive os direitos econômicos, sociais e culturais). O primeiro momento é anterior ao refúgio e se pode afirmar que a violação de direitos humanos e colapso do Estado de Direito constituem a principal fonte de causas que levam à solicitação de refúgio. O segundo momento ocorre quando a pessoa é obrigada a deixar seu país. O terceiro momento é o período de refúgio, durante o qual é do Estado de acolhida a responsabilidade pela tutela dos direitos humanos dos refugiados. O quarto momento corresponde às soluções duráveis, dentre as quais se destacam: (1) repatriação voluntária; (2) integração local; (3) reassentamento em outros países (PIOVESAN, 2001). A visão tradicional concentrava atenção quase que exclusivamente na etapa intermediária de proteção (refúgio). Foram as necessidades de proteção, explica Antônio Augusto Cançado Trindade, que levaram o ACNUR, nos últimos anos, a ampliar seu enfoque de modo a abranger também a etapa "prévia" de prevenção e a etapa "posterior" de solução duradoura (TRINDADE, 2003, p. 396). 


\section{Diálogos entre DIDH, DIH e DIR, na construção da cidadania universal}

Há três vertentes de proteção internacional da pessoa humana, quais sejam: Direito Internacional dos Direitos Humanos (DIDH), Direito Internacional $\mathrm{Hu}-$ manitário (DIH) e Direito Internacional dos Refugiados (DIR). A doutrina clássica, muito preocupada com a separação dos objetos de estudo em razão das origens históricas distintas de cada um dos ramos, acabou por compartimentalizá-los, em prejuízo da vítima.

No propósito de proteção da pessoa humana, em todas e quaisquer circunstâncias, as três vertentes foram revisitadas e passaram a ser entendidas como complementares, mas cada uma manteve seus diferentes meios de implementação e de supervisão. Felizmente, foi superada a visão do passado, e hoje constatam-se as convergências entre os três grandes braços da proteção internacional da pessoa humana. Passou-se, assim, da compartimentalização à interação (TRINDADE, 2003, p. 345).

Marco normativo importante desta doutrina da convergência é a Declaração Universal dos Direitos Humanos (DUDH) de 1948. Com ela, foi introduzida a concepção contemporânea de direitos humanos, segundo a qual eles são universais, inerentes à condição de pessoa e não relativos às peculiaridades sociais e culturais de determinada sociedade. Incluem-se em seu elenco não só direitos civis e políticos, mas também direitos sociais, econômicos e culturais, em face da característica da indivisibilidade dos direitos humanos (PIOVESAN, 2001, p. 28) ${ }^{11}$

A partir dessa concepção de direitos humanos, constrói-se o conceito de cidadania universal, aqui entendida como aptidão para exercer direitos ${ }^{12}$. Pode-se afir-

${ }^{11}$ A universalidade, indivisibilidade, interdependência e o inter-relacionamento dos direitos humanos foram retomados na Declaração e Programa de Ação de Viena, em 1993.

${ }^{12}$ Pode-se buscar nas palavras do jurisconsulto romano Cícero os primeiros delineamentos de uma cidadania universal, quando ele se referiu à communis humani generis societas ("sociedade comum do gênero humano"). Segundo a lição de Fábio Konder Comparato, "[...] em Roma, sob a influência do pensamento estóico, Cícero sustentou que havia um direito natural, que regia não apenas a vida familiar e a vida pública, mas também as relações entre cidadãos e estrangeiros, ou as destes e dos diversos povos entre si. 'Dizer que se deve respeitar os concidadãos, mas não os estrangeiros', afirmou ele no De officiis (III, 28) em fórmula admirável, é destruir a sociedade comum do gênero humano (communis humani generis societas)'. [...] Essa proposta de uma declaração universal dos direitos humanos, como mar que a universalização dos direitos humanos inovou o tema da cidadania ao reconhecer o homem como sujeito de direitos fundamentais, sem qualquer referência à sua nacionalidade (RAMOS, 2008, p. 733), de modo que existe uma cidadania, vinculada à noção de aptidão para exercer direitos, que é universal.

O conteúdo do conceito de cidadania universal pode ser aprofundado com a lição de Habermas trabalhada por Carolina Campos Melo (2001, p. 279). Abordase a problemática da "integração da diferença de forma não homogeneizante", para apontar que o respeito à pluralidade é possível desde que a convivência, nos limites territoriais do Estado, ocorra por intermédio do conceito de 'nação de cidadãos', em contraposição a uma 'nação de cultura'.

Nessa 'nação de cidadãos', a identidade cultural não pode mais responsabilizar-se pela coesão social. As sociedades contemporâneas contêm alto grau de multiculturalismo, de modo que a coesão social deve ser baseada na identidade política, constituindo a cidadania, a estratégia para convivência em sociedades marcadas pela diferença.

Nação de cidadãos' é fruto da preocupação com a forma política e não cultural da coesão social apta a gerar o patriotismo constitucional, enquanto "compromisso com as instituições do Estado de Direito e com a democracia radical", substituto de qualquer lealdade cultural.

Nesse sentido, a cidadania universal, que iguala os homens em razão de sua humanidade, respeita as diferenças, porque se pauta em etnicidades simétricas e na valorização das diferenças culturais ${ }^{13}$, e situa-se no epicentro do diálogo entre o DIDH, o DIR e o DIH.

sabido, só vingou um século e meio depois. O documento aprovado pela Assembleia Geral das Nações Unidas, em 10 de dezembro de 1948, inicia-se pela afirmação de que 'o reconhecimento da dignidade inerente a todos os membros da família humana e de seus direitos iguais e inalienáveis é o fundamento da liberdade, da justiça e da paz no mundo'. Doravante, acima do status de cidadão de um Estado em particular está a condição de ser humano, a qual dispensa qualquer outra qualificação de raça, gênero, nacionalidade ou religião: Todo homem tem direito de ser, em todos os lugares, reconhecido como pessoa perante a lei' (artigo VI)", (COMPARATO, 2005).

${ }^{13}$ Alertam Roberto Marinucci e Rosita Milesi que "[...] é dever da comunidade internacional e de cada ser humano fazer com que o 'novo' trazido pelos migrantes e refugiados seja fonte de enriquecimento recíproco na construção de uma cultura de paz e justiça. É esse o caminho para promover e alcançar a cidadania universal" (MARINUCCI; MILESI, 2006, p. 80). 
A igualdade imanente da cidadania universal determina compromisso dos Estados democráticos com a não discriminação entre nacional e estrangeiro ${ }^{14}$.

\section{0 instituto do asilo e o dever do estado de acolhida de reconhecer o status de refugiado}

No plano normativo internacional global, o direito de asilo em sentido amplo é preconizado no art. 14, da

\footnotetext{
${ }^{14}$ Analisando o direito dos estrangeiros, verifica-se sua oscilação entre momentos de maior e de menor abertura, que influenciaram a normatividade vigente em cada época: (a) a visão tradicional do estrangeiro como elemento estranho à sociedade $\mathrm{e}$ criador de problemas diplomáticos; (b) a visão tradicional do estrangeiro como imigrante, apto a ser integrado por meio de normas de imigração e naturalização; (c) a visão contemporânea, quando o estrangeiro é visto como um cidadão (RAMOS, 2008, p. 725).

No Brasil, as Constituições de 1934 e de 1937 refletem a tendência de restrição de direitos, no que foi seguida pela Constituição de 1946. Com o fim da II Guerra Mundial, o Brasil entrou em um período de expansão, no qual se flexibilizou a política de imigração no que tange à mão-de-obra especializada (DecretoLei $\mathrm{n}^{\circ} 7.967$, de 18/09/1945), mas, por outro lado, manteve-se postura racista, ao privilegiar-se a imigração europeia (MARINUCCI; MILESI, 2006, p. 55).
}

Já a Constituição de 1988 abre-se para outra visão. De início, vêse que ela limitou a titularidade de direitos fundamentais apenas ao "estrangeiro residente". Ocorre que restrição como essa é ofensiva aos princípios fundantes de um Estado Democrático de Direito (art. $1^{\circ}$ ), vez que - conforme interpretação literal, admitir-se-ia a privação do direito à vida ou integridade física do estrangeiro não residente. Em razão disso, é pacífica na doutrina a extensão da titularidade de direitos fundamentais a todos os estrangeiros, que se justifica de diversos modos. Em primeiro lugar, o Estado Democrático de Direito fundado pela Constituição de 1988, regido pelo princípio da razoabilidade, não admitiria a privação de direitos fundamentais com base no critério da "não residência", que não guarda pertinência com o exercício de direitos essenciais. É ofensivo ao fundamento da República que preconiza a promoção da dignidade humana (art. $1^{\circ}$, inciso III) o tratamento de estrangeiros não residentes como desprovidos de direitos. Por fim, nos moldes do art. $5^{\circ}, \$ 2^{\circ}$, reconhecem-se os direitos constitucionais expressos em tratados internacionais de direitos humanos $\left(\operatorname{art} .5^{\circ}, \$ 2^{\circ}\right.$ ) já ratificados pelo Brasil. Considerando que os instrumentos convencionais internacionais de direitos humanos outorgam direitos em razão da humanidade, sepultada está a interpretação literal do caput, do art. 5. (SILVA, 1996, p. 188-190).

No mesmo sentido foi a orientação do Alto Comissariado das Nações Unidas para Refugiados (ACNUR), durante a XIV Cumbre Iberoamericana: "2. Los derechos humanos son aplicables a todas las personas. El ACNUR subraya la importancia de garantizar que los derechos y los estándares laborales de todos los refugiados y migrantes serán respetados. Los principales instrumentos de derechos humanos de las Naciones Unidas son de aplicación universal y generalmente se aplican por igual tanto a nacionales como a no nacionales, incluyendo a quienes se han trasladado de manera irregular" (ACNUR, 2006).
DUDH, na Convenção Relativa ao Estatuto dos Refugiados (Convenção de 1951) ${ }^{15}$ e seu Protocolo Adicional de $1967^{16}$, assim como a Convenção de Viena sobre Relações Consulares $^{17}$, os Convênios de Genebra de 1949 e seus Protocolos Adicionais de 1977.

No plano internacional regional americano, são marcos legais do direito de asilo: a Carta da Organização dos Estados Americanos (OEA) ${ }^{18}$, a Declaração Americana sobre os Direitos e Deveres do Homem, a Convenção Americana sobre Direitos Humanos, também denominada Pacto de San José $(\mathrm{CADH})^{19}$, Protocolo Adicional à Convenção sobre Direitos Humanos em matéria de Direitos Econômicos, Sociais e Culturais (Protocolo San Salvador ${ }^{20}$, Protocolo Adicional à Convenção Americana sobre Direitos Humanos referente à Abolição da Pena de Morte, Convenção Interamericana para Prevenir e Punir a Tortura $^{21}$, Convenção Interamericana para Prevenir, $\mathrm{Pu}$ nir e Erradicar a Violência contra a Mulher (Convenção de Belém do Pará $)^{22}$, Declaração de Cartagena de $1984^{23}$.

Em relação à Carta da OEA, o art. $3^{\circ}$ (1) determina que "os Estados Americanos proclamem os direitos fundamentais da pessoa humana, sem distinção de raça, nacionalidade, credo ou sexo". De acordo com a Declaração Americana sobre Direitos e Deveres do Homem, o Estado deve respeitar os direitos fundamentais do indivíduo, como o direito à vida, à liberdade e à integridade pessoal. Especificamente no tema de refugiados, o artigo XXVII dispõe que: "Toda pessoa tem o direito de procurar e receber asilo em território estrangeiro, em caso de perseguição que não seja motivada por delitos de direito comum, e de acordo com a legislação de cada país e com as convenções internacionais".

A Convenção Americana estabelece no art. 22, que o direito de circulação e de residência resulta em crucial proteção aos refugiados e solicitantes de refúgio, ao

\footnotetext{
${ }^{15}$ Promulgada pelo Brasil, pelo Decreto 50.215, de 28.01.1961.

${ }_{16}$ Promulgada pelo Brasil, pelo Decreto 70.946, de 07.08.1972.

${ }^{17}$ Promulgada pelo Brasil, pelo Decreto 61.078, de 26.07.1967.

${ }^{18}$ Aprovada no Brasil, pelo Decreto Legislativo n. 64, de 07.12.1951.

${ }^{19}$ Promulgada pelo Brasil, pelo Decreto 678, de 06.11.1992.

${ }^{20}$ Promulgada pelo Brasil, pelo Decreto 3.321, de 30.12.1999.

${ }^{21}$ Ratificada pelo Brasil em 20.07.1989.

${ }^{22}$ Promulgada pelo Brasil, pelo Decreto 1.973, de 01.08.1996.

${ }_{23}$ Adotada pelo "Colóquio sobre Proteção Internacional dos Refugiados na América Central, México e Panamá: problemas jurídicos e humanitários", realizado em Cartagena, Colômbia, entre 19 e 22 de novembro de 1984 .
} 
estabelecer tanto o direito ao asilo como o princípio da não devolução:

Artigo 22 (7) Toda pessoa tem o direito de buscar e receber asilo em território estrangeiro em caso de perseguição por delitos políticos ou comuns conexos com crimes políticos e de acordo com a legislação de cada Estado e os convênios internacionais. (8) Em nenhum caso o estrangeiro pode ser expulso ou entregue a outro país, seja ou não de origem, onde seu direito à vida ou à liberdade pessoal esteja em risco de violação em virtude de raça, nacionalidade, religião, condição social ou de suas opiniões políticas.

Nota-se que a normativa regional americana faz expressa referência às convenções internacionais que tratam especificamente do direito de asilo. A decorrência lógica dessa remição normativa consiste no estabelecimento de necessário diálogo entre o sistema global e o regional de proteção de direitos humanos.

No plano operacional, igualmente existe convergência e complementaridade entre o Sistema Interamericano de Direitos Humanos e o DIR. Prega-se que os princípios e regras do sistema universal (isto é, regras sobre DIR no âmbito da Organização das Nações Unidas) formem parte também do sistema interamericano de direitos humanos (SAN JUAN, 2005) ${ }^{24}$.

Segundo a prática da Comissão Interamericana de Direitos Humanos (CIDH), somada à jurisprudência da Corte Interamericana de Direitos Humanos e nos moldes dos princípios gerais de direitos humanos, a $\mathrm{CADH}$ deve interpretar-se teleologicamente para a tutela da pessoa

${ }^{24}$ Ver também: (PULIDO; BLANCHARD, 2007. Ver também: PULIDO, María Claudia; BLANCHARD, Marisol. La comision interamericana de derechos humanos y sus mecanismos de proteccion aplicados a la situacion de los refugiados, apátridas y solicitantes de asilo. Disponível em <http://www.oas. org/dil/xxxiv/Documentos/Juan\%20Carlos\%20Murillo/JCMurillo.comisi\%F3ninteramericanayrefugiados.pdf $>$. Acesso em: 26 set. 2008.). Seu trabalho consiste em passeio pelos mais de 40 anos de labor da Comissão Americana de Direitos Humanos (CIDH), principal órgão de monitoramento de direitos humanos no hemisfério, em matéria de refugiados, solicitantes de asilo e apátridas. Foram estudados todos os informes por país, as contribuições jurisprudenciais e medidas urgentes adotadas por esse órgão de supervisão e também as audiências temáticas. humana, em conformidade com o princípio pro homine $e^{25}$ (artigo 29 da CADH) e tendo o DIR universal como lex speciallis, dentro do marco do art. 22 (7), da CADH.

Em termos comparativos, o sistema interamericano de proteção revela um expressivo potencial de evolução no sentido do diálogo entre as fontes do DIDH e do DIR, em prol da complementaridade das vertentes de tutela da pessoa humana, observa Antônio Augusto Cançado Trindade (2003, p. 425).

Ao se enfocar a natureza jurídica do direito de asilo, segundo a perspectiva da indivisibilidade dos direitos humanos, eventual investigação acerca da geração a que ele pertence perde qualquer interesse ${ }^{26}$. Com base na integração das normas de direitos humanos, pode-se concluir que o conteúdo do direito de buscar e receber asilo contemplado na normativa internacional inclui, como um mínimo, os seguintes elementos: (1) o direito de sair de qualquer país, inclusive do seu próprio; (2) admissão no território; (3) non-refoulement; (4) não discriminação; (5) acesso a um procedimento para determinar se a pessoa reúne os requisitos para ter direito ao asilo; (6) garantias mínimas no decorrer do procedimento: (6.a) o direito de ser ouvido por um juiz ou tribunal competente, independente e imparcial estabelecido por lei; (6.b) assistência de um tradutor se não compreende ou não fala o idioma utilizado no procedimento; (6.c) tempo e meios adequados para preparar seu caso; (6.d) assistência legal; (6.e) o direito de recorrer da decisão ante uma instância superior; (6.f) o direito a um recurso judicial simples e rápido que o ampare contra uma violação do direito de asilo, ao devido processo ou outro direito reconhecido pela Constituição, lei interna ou a tratados internacionais; (7) o exercício efetivo de direitos humanos básicos permite ao solicitante permanecer no país em condições de dignidade e segurança até que se tome decisão definitiva sobre seu caso; (8) o asilo se outorga com base em critérios objetivos previamente estabelecidos e conforme os instrumentos internacionais aplicáveis; (9) a outorga

${ }^{25}$ Definindo interpretação pro homine, André de Carvalho explica que "[...] toda a exegese do Direito Internacional dos Direitos Humanos, consagrada pela jurisprudência internacional, tem como epicentro o princípio da interpretação pro homine, que impõe a necessidade de que a interpretação normativa seja feita sempre em prol da proteção dada aos indivíduos" (RAMOS, 2005, p. 96).

${ }^{26}$ Sobre a divisibilidade dos direitos humanos em gerações, vide: BOBBIO, 1992. 
de asilo está de acordo com a obrigação do Estado de investigar e sancionar violações de direitos humanos ou do direito humanitário ou, em não sendo o caso, de extraditar a pessoa a um país - diverso daquele de onde teme perseguição - que esteja disposto a fazê-lo; (10) a proteção do Estado se vincula com a obtenção de una solução duradoura (integração local, reassentamento em um terceiro país ou repatriação voluntária) (SAN JUAN, 2005).

Esse longo elenco de deveres dos Estados Partes em relação aos refugiados conduz à conclusão de que a natureza jurídica do direito de asilo é complexa. Em essência, portanto, o direito de asilo consiste em feixe de direitos, tendo como fundamento o princípio da solidariedade internacional e o princípio da igualdade material, sendo ambos densificadores ${ }^{27}$ do princípio da dignidade da pessoa humana.

Do ponto de vista jurídico, a solidariedade é norma jurídica da espécie, princípio cujo objetivo central consiste em viabilizar uma "igual dignidade social" (PERLINGIERI, 1999, p. 36-37) ${ }^{28}$. O princípio da solidariedade identifica-se com o conjunto de instrumentos voltados para garantir uma existência digna, comum a todos, em uma sociedade que se desenvolva como livre e justa, sem excluídos ou marginalizados. Nesse sentido, é mais do que um sentimento fraternal ${ }^{29}$, pois tem como conteúdo o respeito pela diferença. Esse aspecto relativo ao princípio

${ }^{27} \mathrm{~A}$ expresssão densificar se refere às possibilidades de maior concretude ou realização da norma jurídica e deve ser entendida no sentido que lhe cunhou J. J. GOMES CANOTILHO (1999).

${ }^{28}$ Para o professor, a solidariedade constitucional (normaprincípio) visa ao pleno desenvolvimento da pessoa humana e, por esta razão, deve ser entendida em relação ao tema da igualdade e da igual dignidade social. Supera-se, assim, o mito do fim superindividual, posto que não se concebe um interesse superior ao do pleno desenvolvimento da pessoa humana.

${ }^{29}$ A professora Maria Celina Bodin de Moraes, ao analisar o princípio da dignidade da pessoa humana, aponta que tem como conteúdo os princípios da igualdade, integridade psicofísica, liberdade e solidariedade e afirma que "[...] a noção de fraternidade seria a inspiração da solidariedade difundida na modernidade - época dos primeiros documentos de declaração de direitos - quando estavam na ordem do dia as ideias assistencialistas, postas em prática por meio da caridade e da filantropia. [...] $\mathrm{O}$ ato beneficente, ou caritativo, permanece sempre como uma liberalidade, uma opção que diz respeito apenas à consciência, não se concebendo em termo de obrigação a não ser moral; ao passo que a solidariedade, nos termos invocados pelo constituinte, é um dever de natureza jurídica" (MORAES, 2001, p. 172-173). da igualdade material deve sobressair para possibilitar a coexistência pacífica das diversas concepções de vida, cientes do que as distingue e do que as une - no caso, a igual dignidade de todas as pessoas humanas.

Paradoxalmente ao que se deflui de uma análise superficial, elevar a dignidade da pessoa humana (e o desenvolvimento da sua personalidade) ao posto máximo do ordenamento jurídico constitui opção metodológica oposta a do individualismo das codificações da época da Revolução Francesa. No novo cenário, sintonizado com a norma-princípio da solidariedade, o valor fundamental deixou de ser a vontade individual (suporte fático-jurídico das situações patrimoniais que importava regular), dando lugar à pessoa humana e à dignidade que lhe é intrínseca. Essa mudança de perspectiva instaura nova ordem calcada na primazia das situações existenciais sobre as situações de cunho patrimonial:

A pessoa humana, no que se difere diametralmente da concepção jurídica do indivíduo, há de ser apreciada a partir da sua inserção no meio social, e nunca como uma célula autônoma, um microcosmo cujo destino e cujas atitudes pudessem ser indiferentes às demais (MORAES, 2001, p. 177).

Sendo a pessoa humana sujeito de Direito Internacional, há de se realizar uma releitura da noção clássica de soberania para bem compreender o binômio: direito humano de buscar e receber asilo e dever do Estado de acolhida de concedê-lo ${ }^{30}$.

Com a consolidação normativa internacional de um catálogo de direitos da pessoa humana e de mecanismos de monitoramento quanto à proteção que o Estado assegura a esses direitos, hoje, descabe qualquer alegação estatal na defesa de suas condutas violatórias de direitos humanos, no sentido de que a proteção de direitos humanos faz parte de seu domínio reservado, e que eventual averiguação internacional da situação interna de direitos humanos ofenderia sua soberania (RAMOS, 2005, p. 78). Não há mais a possibilidade de alegação de competência nacional exclusiva em matéria de direitos humanos.

\footnotetext{
${ }^{30}$ Márcio Pereira Pinto Garcia entende que solidariedade é dever jurídico, cuida não só do direito ao refúgio, mas principalmente do dever de assistir quem dele necessita (GARCIA, 2001, p. 148).
} 
Nesse diapasão, relaciona-se o entendimento da Corte Permanente de Justiça Internacional ${ }^{31}$, segundo o qual, o próprio processo de elaboração de tratados envolve um dos mais importantes exercícios de soberania por parte do Estado, não podendo, em matéria de direitos humanos, ser visto como amesquinhamento da soberania, mas sim a sua plena manifestação.

Este estudo defende, assim, a necessidade de redução do âmbito de discricionariedade do Estado, sob pena de inefetividade na implementação de direitos universalmente assegurados. Adotando-se a perspectiva da proteção dos direitos humanos, faz-se fundamental consolidar a teoria da responsabilidade jurídica do Estado no tocante à matéria, para que ao direito de solicitar asilo e dele gozar corresponda o dever do Estado de Acolhida de conceder asilo (PIOVESAN, 2001, p. 54-55). Sem embargo, a maior parte dos tratadistas sustenta que não existe direito da pessoa a que lhe seja outorgado asilo. Para Celso de Albuquerque Mello (2004, p. 1092), “[...] o direito de asilo, apesar de ter por finalidade proteger a pessoa humana, é ainda considerado um direito do Estado e não do indivíduo". O autor refere-se à orientação dada pela Convenção Interamericana sobre Asilo Territorial (CARACAS, 1954 $)^{32}$ que, no artigo $1^{\circ}$, afirma ser o asilo um direito do Estado, que admite "dentro do seu território as pessoas que julgar conveniente". Não existe, segundo esse raciocínio, qualquer obrigatoriedade do Estado em conceder o asilo, que o faz por meio de ato discricionário (orientação consagrada no artigo $2^{\circ}$ da Convenção Interamericana sobre Asilo Territorial).

Contudo, o próprio Celso Mello (2004, p. 1093).admite que esta orientação predominante

\begin{abstract}
Não deixa de ser criticável. A doutrina (Scelle) tem afirmado que o Estado possui o dever de conceder o asilo. Na verdade, o asilo, instituto essencialmente humanitário, somente atenderá completamente a sua finalidade quando se transformar em um direito do indivíduo e em dever do Estado.
\end{abstract}

Contextualizando o momento em que nasceu o regime de proteção internacional dos refugiados, verifica-se que ele remonta a uma época em que a pessoa humana não era sujeito de direito internacional. Com base nessa consta-

\footnotetext{
${ }^{31}$ Vide: Corte Permanente de Justiça Internacional, Caso S. S. Wimblendon, sentença de 17 de agosto de 1923, P. C. I. J Séries A, n. 1, (1923), p. 25.

${ }^{32}$ Promulgada pelo Brasil, pelo Decreto 55.929, de 14.04.1965.
}

tação, María Teresa Gil-Bazo (2008, p. 810) explica o motivo de os Estados não aceitarem a existência do dever de asilar. Logo, com a mudança de perspectiva ocorrida após a Segunda Guerra Mundial, se o refugiado é pessoa humana, é - também - destinatário de direitos internacionalmente reconhecidos, dentre eles, o direito de buscar e receber asilo, e os Estados são destinatários de deveres para com a pessoa humana do refugiado, tal qual o dever de asilar.

Por um lado, André de Carvalho Ramos (2008, p. 738-739) defende a discricionariedade estatal na admissão de estrangeiros e, por outro, é categórico no sentido de que os solicitantes de refúgio têm direito de ingresso ex jure, em verdadeira exceção à norma internacional costumeira que dispõe caber ao Estado - discricionariamente - permitir ou não a entrada de estrangeiros em seu território.

Para Antônio Augusto Cançado Trindade (2003, p. $428)^{33}$ existe o dever do Estado de acolhida de conceder asilo, sendo certo que esta obrigação internacional decorre do dever geral de proteção dos direitos humanos erga omnes partes. As obrigações erga omnes são devidas à comunidade internacional como um todo, abarcando todos os Estados assim como outros sujeitos do Direito Internacional.

Nesse contexto, reconhece-se a existência de um dever de satisfazer as necessidades básicas de assistência aos seres humanos em toda parte, que têm direito de viver com dignidade. Eles são os titulares do direito à assistência humanitária, ao qual corresponde dever jurídico prestacional, correlato e exigível do Estado de acolhida.

Estabelecidos os parâmetros da proteção internacional dos refugiados, passar-se--á à análise dos marcos legais no plano normativo interno. A proteção do refugiado pelo ordenamento jurídico brasileiro funda-se em dois pilares básicos (JUBILUT, 2007, p. 179): a Constituição Federal de 1988 e a Lei 9.474, de 22 de julho de 1997.

\footnotetext{
33 "Não mais se pode abordar tais obrigações a partir de uma perspectiva ou dimensão estritamente interestatal, que inclusive não mais refletiria a realidade do ordenamento jurídico internacional contemporâneo. $\mathrm{O}$ fenômeno atual da expansão da personalidade e capacidade jurídicas internacionais constitui uma resposta a uma verdadeira necessidade da comunidade internacional de nossos dias. Não só os Estados, mas também todos os demais atores internacionais estão vinculados pelas obrigações erga omnes (como evidenciado pela diversificação atual e lamentável das fontes de violações - da parte dos Estados assim como de agentes não estatais - dos direitos da pessoa humana), devidas à comunidade internacional como um todo".
} 
Com base nos princípios constitucionais que regem as relações internacionais (artigo $4^{\circ}$ ) e no princípio da dignidade da pessoa humana (artigo $1^{\circ}$, III), pode-se afirmar que os alicerces da concessão do refúgio são expressamente assegurados pela Constituição Federal de 1988. Do princípio da dignidade da pessoa humana, epicentro axiológico do ordenamento jurídico brasileiro, decorre o princípio da solidariedade, que está insculpido no artigo $3^{\circ}$, I e é base do direito de asilo. Ele foi destacado no Texto Constitucional, no Título I, denominado "Dos Princípios Fundamentais" e, como tal, a sua essencialidade faz com que desfrutem de preeminência, seja na sua realização pelos poderes públicos e demais destinatários do ditado constitucional, seja na tarefa de interpretá-los e, à sua luz, interpretar todo o ordenamento jurídico nacional (MORAES, 2001, p. 168).

O princípio da igualdade substancial, que complementa o da solidariedade, ganha assento no caput do artigo $5^{\circ}$ da Constituição Federal de $88(\mathrm{CF} / 88)$ e se refere aos estrangeiros residentes, mas é ampliado a todos os seres dotados de humanidade, ou seja, qualquer pessoa humana.

No art. $4^{\circ}$ estão enumerados os princípios constitucionais reitores das relações internacionais da República Federativa do Brasil. Dentre eles, destaca-se a referência expressa ao direito de asilo (inciso X - concessão de asilo político), à cooperação entre os povos para o progresso da humanidade (inciso IX), ao repúdio ao terrorismo e ao racismo (inciso VIII).

Um passeio pela CF/88 demonstra que, além de manifestar o repúdio ao racismo e ao terrorismo como princípio de política externa, a normativa constitucional considera sua prática como inafiançável e imprescritível, nos termos do art. $5^{\circ}$, inciso XLII. Considerando que o respeito aos direitos humanos tem como uma de suas bases fundamentais a não discriminação, seria um contraditio erigir o repúdio ao racismo e ao terrorismo como princípio constitucional de política externa e discriminar o refugiado não lhe assegurando condições para se integrar no Estado de acolhida.

Derivado do princípio da solidariedade internacional está o princípio da política externa da cooperação entre os povos para o progresso da humanidade. Ele constitui fonte de restrições à discricionariedade estatal, uma vez que impõe aos Estados razoabilidade nas respostas aos requerimentos da comunidade internacional, quando o objetivo seja atender às necessidades de proteção dos refu- giados. Tais responsabilidades deverão ser casuisticamente avaliadas e estar sintonizadas com o princípio da boa-fé (SAN JUAN, 2005).

Além disso, o princípio da solidariedade guarda uma importante conotação ética que deve ser entendida como uma meta a ser constantemente perseguida, pois “o progresso comporta não só o avanço cultural, tecnológico, econômico ou material, mas também seu compartilhamento e gozo pelos povos em seu conjunto e, sobretudo, o progresso do ser humano em toda a sua plenitude e dignidade" (GOFFREDO, 2001, p. 204).

Quando a CF/88, no art. 4º, X, (POGREBINSCHI, $2001)^{34}$ erigiu a concessão de asilo político como princípio reitor das relações internacionais, englobou qualquer das formas de asilo (seja político ou asilo propriamente dito, seja territorial ou refúgio). A concessão do asilo é importante instrumento de proteção à pessoa humana e a sua elevação como princípio de política externa denota e acentua a preocupação do Constituinte com a prevalência dos direitos humanos (artigo $4^{\circ}$, II) e da democracia ${ }^{35}$.

Por um lado, mesmo se revestindo na forma de princípio, o asilo pode ser reclamado como um direito subjetivo individual (POGREBINSCHI, 2001, p. 341) ${ }^{36}$. E, por outro, em sendo os princípios diretrizes a serem

${ }^{34}$ A autora apresenta estudo realizado nos anais da constituinte e explica como o direito de asilo, no segundo turno de votações no plenário, ganhou a forma que ocupa no texto constitucional, passando de dispositivo do rol de direitos e garantias individuais para princípio informador das relações internacionais.

${ }^{35}$ Celso D. de Albuquerque faz duas observações ao artigo $4^{\circ}$, X, da Constituição de 88. "A primeira observação que deve ser feita é que ela abrange asilo diplomático e o asilo territorial. A segunda observação é que, apesar de tudo, não surge uma obrigatoriedade da concessão de asilo, vez que a qualificação do indivíduo como perseguido político é da competência do Poder Executivo, que se trata de matéria de política externa. Por outro lado, o art. $4^{\circ}$ é uma norma programática (2004, p. 1093). Em que pese a autoridade do autor e o fato de seu posicionamento estar em consonância com a doutrina majoritária, neste trabalho se adota entendimento diverso.

${ }^{36}$ Afirma a autora: "E finalmente, quanto à aplicabilidade ou eficácia do dispositivo em face da sua conceituação como um princípio, discordamos da doutrina mencionada para afirmar que não se tratam de princípios de normas programáticas, nem mesmo de normas de eficácia contida. Os princípios e, principalmente, os princípios fundamentais da Constituição, são normas que possuem a mesma força cogente e vinculante das demais regras do texto constitucional. Portanto, o asilo, enquanto um direito fundamental positivado na forma de princípio, pode ser normalmente exigido por seus titulares em face do Estado brasileiro, obrigado a concedê-lo". 
seguidas, o Estado brasileiro deve conceder o asilo sempre que o solicitante se enquadrar nas hipóteses legais. Trata-se de norma jurídica plenamente aplicável e efetiva, com forte caráter promocional.

Com as "normas promocionais" (PERLINGIERI, 1999, p. 2, 57), dotadas de alta carga valorativa, o Direito torna possível a transformação social. Mas não são quaisquer os valores inspiradores das normas. A tábua axiológica do ordenamento jurídico de um Estado está na sua Constituição. E, ao considerar o papel unificador das normas constitucionais, que são hierarquicamente superiores a todas as demais e diretamente aplicáveis (isto é, independem de normas infraconstitucionais), fixam-se as premissas para a construção da teoria moderna de interpretação da norma.

O papel unificador da Constituição relaciona-se com a finalidade que têm as normas constitucionais de conferir unidade (consistência e coerência) ao sistema jurídico do Estado. A Constituição é uma "unidade dividida (Badura), dada a diferente configuração e significado material das suas normas" (CANOTILHO, 1999, p. 1169) ${ }^{37}$, o que em nada compromete a "igualdade hierárquica de todas as suas regras e princípios quanto à sua validade, prevalência normativa e rigidez". Há íntima ligação das ideias de unidade e de hierarquia entre normas jurídicas. Daí estarem correlacionados os princípios da unidade e da superioridade normativa da Constituição.

Considerar a Constituição como sistema normativo aberto de regras e princípios, além de dar sentido útil ao princípio da unidade: o de "unidade hierárquico-normativa", diverso daquele trazido pela doutrina tradicional (BOBBIO, 1996), que a ele recorria para afirmar que o ordenamento jurídico consistia em sistema dotado de unidade, coerência, harmonia e completude (plenitude), viabiliza a tutela das demandas contemporâneas ao ampliar o espectro de abrangência da norma em relação à realidade fática.

Se as normas constitucionais têm força normativa, e se normas são regras e princípios, a única interpretação válida é no sentido de que as normas constitucionais veiculadoras de princípios também têm força normati-

\footnotetext{
${ }^{37} \mathrm{O}$ autor correlaciona a dificuldade de se manter o dogma da unidade da ordem jurídica com a pluralidade de fontes de direito.
}

va, aqui entendida como aplicabilidade direta ${ }^{38}$. Por essa e não por outra razão J. J. Gomes Canotilho decretou a "morte" das "normas constitucionais programáticas", em decidida ruptura à doutrina clássica, que lhes atribui valor de mera carta de intenções. Hoje, a essas normas é reconhecido um valor jurídico constitucionalmente idêntico ao dos restantes preceitos da Constituição, a significar:

(1) vinculação do legislador, de forma permanente, à sua realização (imposição constitucional); (2) vinculação positiva de todos os órgãos concretizadores, devendo estes tomá-las em consideração como directivas materiais permanentes, em qualquer dos momentos da actividade concretizadora (legislação, execução, jurisdição); (3) vinculação, na qualidade de limites materiais negativos, dos poderes públicos, justificando a eventual censura, sob a forma de inconstitucionalidade, em relação aos actos que as contrariam.

Logo, é indene a dúvidas que todas as normas constitucionais são dotadas de igual normatividade, competindo "ao Direito Constitucional realçar, despertar e preservar a vontade de Constituição (Wille zur Verfassung)" (HESSE, 1991, p. 27): maior garantia de sua força normativa.

Buscando fundamento de validade nas normas constitucionais expressas na $\mathrm{CF} / 88$ e nas normas constitucionais expressas em tratados de direitos humanos (art. $5^{\circ}$, parágrafos $1^{\circ}$ e $2^{\circ}$ ) (PIOVESAN, 2008), o legislador infraconstitucional elaborou e aprovou o "Estatuto do Refugiado", consubstanciado na Lei no. 9.474, de 22 de julho de 1997. Trata-se de marco do ordenamento jurídico brasileiro, não só por implementar via legislação ordinária um tratado de DIDH, mas porque estabeleceu os critérios de reconhecimento do status de refugiado, determinou o procedimento para esse reconhecimento e criou, inclusive, um órgão administrativo competente para tratar do tema, o Comitê Nacional para Refugiados (CONARE), vinculado ao Ministério da Justiça. Com essa normativa, o Brasil passou "[...] a ter um sistema

\footnotetext{
${ }^{38}$ Para Canotilho, "aplicabilidade directa significa, desde logo, nesta sede - direitos, liberdades e garantias - a rejeição da "ideia criacionista" conducente ao desprezo dos direitos fundamentais enquanto não forem positivados a nível legal” (CANOTILHO, 1999, p. 1164). Também: "a aplicação directa dos direitos fundamentais implica ainda a inconstitucionalidade de todas as leis pré-constitucionais contrárias às normas da constituição consagradoras e garantidoras de direitos, liberdades e garantias ou direitos de natureza análoga" (CANOTILHO, 1999, p. 1165, grifo do autor).
} 
lógico, justo e atual de concessão de refúgio, razão pela qual tem sido apontado como paradigma para a uniformização da prática e do refúgio na América do Sul, apesar de sempre haver espaço para melhoras e aperfeiçoamento" (JUBILUT, 2007, p. 196) ${ }^{39}$.

\section{Do direito à identidade pessoal do refugiado versus a invisibilidade do indocumentado}

A medula da proteção internacional é o princípio de não devolução (non refoulement), segundo o qual nenhum ser humano deve ser forçado a retornar contra sua vontade a um país onde sua vida ou liberdade corra perigo devido à sua raça, religião, nacionalidade, pertencimento a determinado grupo social ou opiniões políticas. Ocorre que a proteção aos refugiados deve incluir tanto sua segurança física como sua dignidade humana, razão pela qual se estende à assistência para satisfazer suas necessidades básicas (OFICINA DEL ALTO COMISIONADO DE LAS NACIONES UNIDAS PARA REFUGIADOS, 2000).

Nesse diapasão, a cidadania é inclusiva, devendo garantir o acesso à documentação, aos direitos sociais e econômicos básicos e aos serviços públicos. Ao pleitear auxílio humanitário, o refugiado recebe inicialmente a proteção expressa de maneira formal em um documento. É o reinício de sua cidadania. Muitas vezes é o primeiro documento que recebe lhe conferindo a condição de cidadão. Nesse caso, é o início de sua cidadania. Saliente-se que grandes populações não documentadas, pela primeira vez, têm um documento ao se tornarem refugiadas. "Tremendo paradoxo: deixar seu país de origem para ser reconhecido como cidadão no estrangeiro!" (VARESE, 2006, p. 9).

Entretanto, esse paradoxo de ser reconhecido como cidadão no estrangeiro reflete a importância fundamental da proteção internacional e a necessidade de defender esse espaço como um fator de conscientização da humanidade

\footnotetext{
${ }^{39}$ Também: "A proteção aos refugiados, apesar de garantida internacionalmente, realiza-se efetivamente no interior dos Estados. Por isso, os instrumentos internacionais que tratam da matéria facultaram a esses a elaboração de regras mais benéficas e mais adequadas às suas realidades [...]. A proteção aos refugiados, apesar de garantida internacionalmente, realiza-se efetivamente no interior dos Estados. Por isso, os instrumentos internacionais que tratam da matéria facultaram a esses a elaboração de regras mais benéficas e mais adequadas às suas realidades." (JUBILUT, 2007, p. 190).
}

para consolidar as bases de um exercício plural, no marco do direito e da construção democrática ${ }^{40}$.

\subsection{Do direito humano à identidade pessoal}

A doutrina do direito civil-constitucional indica que "[...] para as pessoas físicas, o nome, e mais limitadamente, o sobrenome, mais que direitos isoladamente vistos, são manifestações de uma situação global, estritamente relacionada ao perfil unitário da personalidade" (PERLINGIERI, 1999, p. 180).

O professor italiano Adriano de Cupis classifica o direito ao nome como um dos aspectos do direito à identidade pessoal, que é direito da personalidade (DE CUPIS, 1993) ${ }^{41}$, dada a necessidade da pessoa de afirmar a própria individualidade, distinguindo-se dos outros indivíduos, e, por consequência, ser conhecido por quem é na realidade.

No plano internacional da proteção dos direitos humanos, o direito à identidade é interdependente ou imanente de outros direitos, como o direito a ser registrado, o direito ao nome, o direito à nacionalidade e o direito à personalidade jurídica e também os direitos vinculados à família e à sucessão. Por tal motivo, a Corte Interamericana de Direitos Humanos (2004) interpreta que o direito à identidade "[...] foi reconhecido pela jurisprudência e pela doutrina tanto como direito autônomo quanto como

${ }^{40} \mathrm{O}$ ACNUR, durante a XIV CUMBRE INTERAMERICANA, na conclusão oitava, indica a relação entre não discriminação, inclusão social e tolerância com a otimização do impacto da migração sobre o desenvolvimento do Estado de Acolhida: "8. Promover la inclusión social y la tolerancia puede maximizar el impacto de desarrollo de la migración. Los refugiados y los migrantes se enfrentan al racismo y la xenofobia en muchas partes del mundo, y a menudo están en riesgo de ser marginados por la sociedad y la economía. El ACNUR desea llamar la atención de la XVI Cumbre Iberoamericana sobre los peligros de esta situación, tanto para los derechos como para el bienestar de los mismos refugiados y migrantes, así como para la cohesión de las sociedades en las que viven. El ACNUR exhorta a los Estados participantes en la Cumbre para que contrarresten todas las formas de intolerancia y para que adopten medidas activas para promover la inclusión y la participación económica de los no nacionales, especialmente refugiados y migrantes" (ACNUR, 2006).

${ }^{41}$ Neste trabalho, segue-se a lição do professor italiano que define direitos da personalidade fazendo relação à essencialidade deles. (p. 13-18). 
expressão de outros direitos ou como um elemento constitutivo destes" 42 .

O registro de nascimento é a primeira identificação da pessoa e, por isso, constitui a origem de sua existência frente ao Estado, como cidadã. Considerando que o reconhecimento do direito à identidade é um dos meios pelo qual se efetiva o exercício aos direitos políticos e civis (como o direito a votar, à igualdade diante da lei, à família) e direitos econômicos, sociais e culturais (como saúde e educação), ele é essencial para a participação em uma sociedade democrática ${ }^{43}$.

São diversos os instrumentos internacionais de tutela da pessoa humana que compõe o corpus iuris atinente a esta matéria, podendo-se citar, exemplificativamente, no panorama global: a DUDH (1948), o art. VI (“Todo ser humano tem direito, em todas as partes, ao reconhecimento de sua personalidade jurídica”); o Pacto Internacional sobre Direitos Civis e Políticos (1966), art. 16 (“Toda pessoa terá o direito, em qualquer lugar, ao reconhecimento de sua personalidade jurídica"), art. 24. 2 (“Toda criança deverá ser registrada imediatamente após o seu nascimento e deverá receber um nome").

No panorama regional, a Declaração Americana dos Direitos e Deveres do Homem (1948), o art. XVII (“Toda pessoa tem o direito de ser reconhecida, seja onde for, como pessoa com direitos e obrigações, e a gozar dos direitos civis fundamentais"); a CADH (1969) ou "Pacto de San José”, art. 3º (direito ao reconhecimento da personalidade jurídica: “Toda pessoa tem direito ao reconhecimento de sua personalidade jurídica”), art. 18 (direito ao nome: "Toda pessoa tem direito a um prenome e aos nomes de seus pais ou ao de um desses. A lei deve regular a forma de assegurar a todos esse direito, mediante nomes fictícios, se for necessário.") e art. 20 (direito à nacionalidade: “1. Toda pessoa tem direito a uma nacionalidade.”) c/c no art. art. $5^{\circ}, \$ \$ 1^{\circ}$ a $3^{\circ}$, da Constituição da República Federativa do Brasil, que prevê a adoção das normas dos tratados e dos quais foi signatário e que preencheram os

${ }^{42}$ Neste mesmo caso, a Corte indica que "[...] o direito à identidade está estreitamente ligado ao direito ao reconhecimento da personalidade jurídica, ao direito a ter um nome, uma nacionalidade, uma família e a manter relações familiares..

${ }^{43}$ AG/RES. 2286 (XXXVII-0/07), aprovada na quarta sessão plenária, realizada em 5 de junho de 2007, dispõe sobre o Programa Interamericano de Registro Civil Universal e Direito à Identidade da Organização dos Estados Americanos (OEA). requisitos formais de incorporação perante a lei interna.

No direito brasileiro, a posição da cidadania e da dignidade da pessoa humana como fundamentos da República (CF/88, art. $1^{\circ}$, II e III), juntamente com as garantias de igualdade material (art. $3^{\circ}$, III) e formal (art. $5^{\circ}$ ), constroem uma cláusula geral da personalidade, que representa o ponto de referência para todas as situações nas quais algum aspecto ou desdobramento da personalidade esteja em jogo, estabelecendo com decisão a prioridade a ser dada à pessoa humana, que é o valor fundamental do ordenamento, e está na base de uma série (aberta) de situações existenciais, nas quais se traduz a sua incessantemente mutável exigência de tutela (DONELA, 2003, p. 46).

Surge, então, o direito de adquirir um nome, a qualquer tempo, após o fato nascimento. Todas as vezes que não ocorre o registro do nascimento de um indivíduo em tempo oportuno, poderá este tardiamente o fazer, densificando o princípio constitucional da dignidade da pessoa humana, corolário do Estado Democrático de Direito.

Quando se tratar de refugiado ou solicitante de refúgio, esse direito se subordina a estatuto próprio, objeto da análise deste estudo, no item 3.3.

\subsection{Da relação condicionante do direito à identidade pessoal do refugiado e a efetividade do exercício pleno de sua cidadania universal}

Percebe-se um abismo entre o rol de direitos assegurado pelos documentos internacionais e internos e sua efetividade.

A noção da efetividade é muito importante de ser incorporada ao conteúdo do direito para dotá-lo de real força jurídica efetiva. Enquanto a absorção dos "direitos" pelo "direito" não ocorrer, aqueles permanecem latentes, na qualidade de uma simples promessa de direito, só se tornando "efetivos e eficientes quando o direito do Estado deles se apropria e os transporta para outra ordem" (GOYARD-FABRE, 2002, p. 33-34).

Esclarecendo o conteúdo da expressão “eficácia social da norma”, Eros Roberto Grau (2003, p. 275) entende que seu conceito coabita com o de efetividade do direito. Designa o modo de apreciação das consequências das normas jurídicas e de sua adequação aos fins por eles visados. "Eficácia, então, implica realização efetiva dos resultados buscados pela norma”. 
Segundo José Afonso da Silva (1998, p. 58), a eficácia jurídica designa a qualidade de produzir, em maior ou menor grau, efeitos jurídicos, ao regular desde logo as situações, relações e comportamentos nela indicados. Assim, a eficácia diz respeito à aplicabilidade, exigibilidade ou executoriedade da norma, como possibilidade de sua aplicação jurídica. Repita-se: possibilidade e não efetividade.

Apenas com a exaltação de seus antagonismos e solidariedades é que há possibilidade de dada sociedade ser democrática. Segundo Luis Alberto Warat (1995, p. 124) para se "[...] realizar uma forma de vida democrática, não se pode seguir julgando o dualismo do ser e do dever ser, para ver quem encontra primeiro a homogeneidade mais pura." Faz-se necessário produzir a lei em cada ação social e não consumi-la a partir de sua aceitação pela moral dominante, a significar que continuamente redefine-se o sentido da norma, por meio dos valores constitucionais sintonizados com a realidade social, visando ampliar seu espectro de tutela jurídica, a significar maior e real eficácia social da norma ${ }^{44}$.

Nesse diapasão, a solidariedade e o recomeçar para os refugiados pressupõem igualdade de oportunidades e de acesso aos serviços públicos básicos, acesso à moradia e espaços laborais. As políticas públicas (MILESI, 2007) (5 $^{45}$ voltadas à assistência e integração dos refugiados são im-

\footnotetext{
${ }^{44}$ A redefinição do sentido da norma, por meio dos valores constitucionais sintonizados com a realidade social, como busca de sua eficácia social é traduzida por parte da doutrina como filtragem constitucional da norma. Há alguma polêmica ao redor do termo, que deve ser entendido no sentido que Paulo Ricardo Schier lhe confere, ou seja: mais no sentido de "contaminação" do sistema infraconstitucional à luz dos princípios constitucionais do que de "purificação". Da lição de preeminência normativa da Constituição extrai-se, em sentido positivo, a exigência de que se faça uma leitura (ou releitura) da ordem infraconstitucional através daquela. Essa releitura é denominada de processo de "filtragem constitucional", enquanto atividade hermenêutica e de controle de constitucionalidade das normas infraconstitucionais (SCHIER, 1999, p. 104).

${ }^{45}$ MILESI, Rosita. Dia mundial do refugiado 2008: o desafio das políticas públicas. Edital: notícias da América Latina e Caribe. Disponível em <http://www.adital.org.br/site/noticia.asp?lang=PT\&cod $=33572>$. Acesso em: 26 set. 2008. "O Brasil - com o aprofundamento da temática e o debate sobre a importância do acesso dos refugiados aos direitos sociais, culturais, econômicos - vem reconhecendo, em âmbito legal e teórico, a necessidade de inclusão dos refugiados nas políticas existentes, bem como, em alguns casos, implementação de políticas específicas, ao amparo da disposição constitucional que garante tratamento igualitário aos brasileiros e estrangeiros residentes no país."
}

prescindíveis para assegurar-lhes uma efetiva integração social, econômica e cultural, em especial o acesso ao trabalho, saúde e educação.

Ocorre que, para o refugiado exercer os direitos inerentes à sua cidadania, é necessário que deixe a invisibilidade. Se por um lado, a simples documentação do indivíduo, dando-lhe condições de residência e trabalho no país, não é suficiente para a integração (BARRETO, 2003, p. 205), por outro lado é condição sine qua non para o exercício de direitos, que só assim se tornam potencialmente efetivos.

\subsection{Da norma dirigida à documentação do refugiado e solicitante de refúgio nos marcos legislativos da Convenção 1951 e do Estatuto Brasileiro do Refugiado}

No marco legal da Convenção de 1951, a regra insculpida no art. 27 faz expressa referência ao dever do Estado-Membro de documentar o refugiado, entregando-lhe "papéis de identidade", ou - na dicção do art. 28 - "documentos de viagem".

Trata-se de obrigação que incide desde o momento de ingresso no Estado de acolhida e impõe tratamento inclusivo, sem discriminação, tanto para o refugiado que não era documentado no seu país de origem como para aquele que já possuía documentos de viagem. Essa preocupação normativa explica-se em virtude da situação fática de os refugiados serem - em regra - fugitivos que não tiveram tempo de programar uma viagem. Por isso, deles não se pode exigir visto de ingresso ou qualquer outro tipo de autorização de ingresso no território e mais ainda, não se pode criminalizar o ingresso não documentado no território do Estado de acolhida, conforme se deflui do art. 31, da Convenção de 1951.

A norma-regra brasileira da Lei 9474/97 determina que o procedimento para reconhecimento do status de refugiado seja sigiloso (art. 20) e se inicie com a entrada do solicitante no Brasil e o pedido de refúgio formulado à autoridade migratória (art. 17). Assim, o agente em atuação no Departamento de Polícia Marítima, Aérea e de Fronteiras da Polícia Federal lavra um Termo de Declaração, no qual constam as razões pelas quais se está solicitando refúgio e as circunstâncias da entrada do solicitante no território nacional, além dos dados pessoais básicos dos solicitantes, tais como sua qualificação civil, e a existência ou não de cônjuge e descendentes (JUBILUT, 2007, p. 197). 
Recebida a solicitação de refúgio, o Departamento de Polícia Federal emitirá protocolo (art. 21) em favor do solicitante e de seu grupo familiar que se encontre no território nacional, o qual autorizará a estada até a decisão final do processo. Chamada de autorização de residência provisória pela Lei Federal e regulamentada pela Resolução Normativa CONARE n. 06, de 26.05.1999 (ACNUR, 1999), este documento tem duas questões a serem apontadas: a forma pela qual é apresentada e seu prazo de validade.

A autorização provisória de residência - que assegura a estada legal no Brasil até o final do procedimento no CONARE e permite que o Ministério do Trabalho expeça Carteira de Trabalho e Previdência Social provisória $^{46}$, para o exercício de atividade remunerada no país - é concretizada numa tira de papel, de gramatura comum, com $6 \mathrm{~cm}$ x $20 \mathrm{~cm}$. Nela constam: uma foto, o número do protocolo da solicitação do refúgio, uma rubrica do agente federal, com carimbo e a data de validade do documento.

O prazo de validade da autorização provisória é de 90 dias. Três meses pode parecer um prazo longo, mas a práxis demonstra o contrário. Os procedimentos de solicitação de refúgio, quando demoram mais tempo em tramitação, impõem carimbos sucessivos na tira de papel que consubstancia a autorização provisória, dando-lhe péssimo aspecto, como se estivesse sendo rasurada.

Com esse documento, espera-se que o solicitante de refúgio ${ }^{47}$ consiga obter sua CTPS provisória, realizar contrato de abertura de conta-corrente (pela qual - por

${ }^{46}$ Insta destacar que "a emissão da Carteira de Trabalho e Previdência Social - CTPS, a cargo das Delegacias Regionais do Ministério do Trabalho e Emprego (MTE), encontra-se regulamentada pela Resolução Normativa $n^{\circ}$. 07, de 06 de agosto de 2002, do CONARE, e pelo Ofício-Circular no. 103/2006 - CIRP/CGSAP/DES/SPPE/MTE. Este, objetivando evitar eventual discriminação por parte do mercado de trabalho conforme solicitado pelo próprio CONARE, traz interessante determinação no sentido de não se utilizar a nomenclatura 'REFUGIADO' na identificação do documento laboral, substituindo-se pelas expressões: 'ESTRANGEIRO COM BASE NA LEI n. 9.474 DE 22/07/1997', para as Carteiras definitivas; e 'ESTRANGEIRO COM BASE no art. $21, \$ 1^{\circ}$ da LEI ${ }^{\circ}$. 9.474 DE 22/07/1997', para as Carteiras provisórias." (BARBOSA; HORA, 2006, p. 60).

${ }^{47}$ Considerando que o reconhecimento da condição de refugiado é ato meramente declaratório, nos moldes do art. 26, da Lei 9474/97, tanto o solicitante de refúgio como o refugiado têm direito ao mesmo estatuto protetivo especial. exemplo - receberá eventual remuneração pelo exercício de atividade laborativa remunerada, conforme autoriza a lei), matricular-se na rede de ensino (pública ou privada), contrair casamento, ou qualquer outro ato da vida civil.

Quando o procedimento administrativo do CONARE finda com o reconhecimento da condição de refugiado, o art. 28, da Lei 9474/97 lhe assegura o direito a uma "cédula de identidade" cuja emissão se subordina aos mesmos padrões e características dos documentos emitidos para os demais estrangeiros registrados no país e são definidos no art. 30, da Lei 6815/80.

Ocorre que a validade da Carteira de Identidade de Estrangeiro (CIE) é pequena (em média de 6 meses a 1 ano) e o refugiado não se liberta daquela "tirinha de papel", vez que apresenta a CIE acompanhada do respectivo protocolo de renovação. Como não é incomum que o prazo para renovação precise ser prorrogado, esse novo protocolo também ganha sucessivos carimbos e costuma se deteriorar com os meses e o uso.

Muitas são as situações de desrespeito de direitos que poderiam ser evitadas, desde que se garantisse a efetividade do direito à identidade pessoal do refugiado. Em exemplo de hipotético desrespeito ao direito de matricular-se em uma escola pública, sob o argumento de que não foi apresentada certidão de nascimento (muitas vezes o refugiado não a tem ou ela se extraviou e não há possibilidade de uma $2^{\text {a }}$ via ser solicitada ao Consulado, vez que ele está fugindo de seu país), cabe ação judicial contra o ente federativo que fiscaliza a aludida unidade escolar. Assim como é possível demandar o Estado brasileiro para ter garantido o benefício assistencialista da prestação continuada, desde que atendidos os requisitos da Lei Orgânica de Assistência Social ${ }^{48}$.

Ainda há de se ressaltar que o eventual desrespeito à proteção dos direitos humanos do refugiado não remediado pelo Estado de acolhida pode redundar em respon-

\footnotetext{
${ }^{48}$ No labor do Núcleo de Defesa dos Direitos Humanos da Defensoria Pública do Estado do Rio de Janeiro, que recebe refugiados em razão de convênio firmado com a Cáritas Arquidiocesana (Processo Administrativo E-20/10410/2004), várias demandas têm sido solucionadas extrajudicialmente com a explicação - em ofício à autoridade coatora - de que os refugiados gozam de estatuto protetivo especial e que a autorização provisória de residência ou a CIE são seus papéis de identidade, hábeis a lhes permitir exercer todos os atos da vida civil, em pé de igualdade com o nacional, sob pena de violação do direito líquido e certo à identidade pessoal.
} 
sabilidade internacional perante os órgãos internacionais de tutela da pessoa humana, tal como a Comissão e a Corte Interamericana de Direitos Humanos ${ }^{49}$.

Quando um país acolhe um estrangeiro que perdeu a proteção do Estado em sua terra natal e por isso encontra-se perseguido e desterrado, prevalece a pessoa humana (BARBOSA; HORA, 2006, p. 5).

\section{Conclusão}

Ao término deste estudo, torna-se possível sintetizar objetivamente algumas das suas proposições mais importantes:

1. O século XXI foi inaugurado sem que se expurgasse do cenário internacional a necessidade de alguns indivíduos buscarem refúgio, sendo certo que os migrantes (gênero no qual se inserem os refugiados) revelam a dimensão negativa do celebrado processo de globalização, que estabelece um "duplo regime de circulação", ao abrir as fronteiras para mercadorias e capitais e, simultaneamente, inibir a mobilidade humana. São denúncias vivas da desigualdade e representam a encruzilhada entre a soberania dos Estados-Nação e a proteção dos direitos humanos.

2. A partir da noção de complementaridade e interação entre o DIDH, o DIH e o DIR, constrói-se uma nova concepção de direitos humanos que preconiza sua universalização e indivisibilidade. Assim, universaliza-se também a noção de cidadania - aqui entendida como aptidão para exercer direitos - ao reconhecer o homem como sujeito de direitos fundamentais, sem qualquer referência a sua nacionalidade.

3. A igualdade imanente da cidadania universal determina compromisso dos Estados democráticos com

\footnotetext{
${ }^{49}$ As situações mais dramáticas são protagonizadas por aquele estrangeiro que está em fuga de seu país, que perdeu sua nacionalidade ou que nunca foi por lá registrado (de modo que não teve garantidos os direitos ao nome, à personalidade jurídica e à nacionalidade) e aqui negaram sua qualidade de refugiado mas que, por razões humanitárias e em nome do princípio do non refoulement são mantidos no Brasil. Entende-se, no marco do conceito de cidadania universal, que o Brasil deve registrá-lo tardiamente como nacional. Isso porque foi assumido o compromisso internacional pela erradicação da apatridia. Trata-se de tema que merece um estudo específico e aprofundado, que se afasta do objeto deste trabalho.
}

a não discriminação entre nacional e estrangeiro.

4. A natureza jurídica do direito de asilo é complexa, posto que, em essência, ele consiste em feixe de direitos, tendo como fundamento o princípio da solidariedade internacional e o princípio da igualdade material, sendo ambos densificadores do princípio da dignidade da pessoa humana.

5. Sendo a pessoa humana sujeito de direito internacional, há de se realizar uma releitura da noção clássica de soberania para bem compreender o binômio: direito humano de buscar e receber asilo e dever do Estado de acolhida de concedê-lo. Este estudo defende a necessidade de redução do âmbito de discricionariedade do Estado, para que ao direito de solicitar asilo e dele gozar corresponda o dever do Estado de Acolhida de conceder asilo.

6. A proteção do refugiado pelo ordenamento jurídico brasileiro funda-se em dois pilares básicos: a CF/88 e a Lei 9.474, de 22 de julho de 1997. Naquela, especialmente com base nos princípios constitucionais que regem as relações internacionais (art. $4^{\circ}$ ) e no princípio da dignidade da pessoa humana (art. $\left.1^{\circ}, \mathrm{III}\right)$, epicentro axiológico do ordenamento jurídico brasileiro, do qual decorrem o princípio da solidariedade (art. $\left.3^{\circ}, \mathrm{I}\right)$ e o princípio da igualdade material (art. $5^{\circ}$, caput); pode-se afirmar que os alicerces da concessão do refúgio são expressamente assegurados.

7. Por se revestir na forma de princípio, que é norma jurídica plenamente aplicável e efetiva dotada de forte caráter promocional, o asilo pode ser reclamado como um direito subjetivo individual sempre que o solicitante enquadrar-se nas hipóteses legais, não podendo o Estado brasileiro se furtar a concedê-lo.

8. Buscando fundamento de validade nas normas constitucionais expressas na Constituição e nas normas constitucionais expressas em tratados de direitos humanos (art. $5^{\circ}$, parágrafos $1^{\circ}$ e $2^{\circ}$ ), o legislador infraconstitucional elaborou e aprovou o "Estatuto do Refugiado", consubstanciado na Lei $n^{\circ}$. 9.474, de 22 de julho de 1997, da qual se destacam os dispositivos relativos à documentação do refugiado, que lhe garantem o exercício do direito à identidade.

9. No plano da proteção dos direitos humanos, o direito à identidade é interdependente ou imanente de outros direitos, como o direito a ser registrado, o direito 
ao nome, o direito à nacionalidade e o direito à personalidade jurídica e também os direitos vinculados à família e à sucessão.

10. No direito brasileiro, todo o tecido normativo infraconstitucional é modelado pela tábua axiológica eleita pelo constituinte e, em tema de direito à identidade, há uma cláusula geral da personalidade, que representa o ponto de referência para todas as situações nas quais algum aspecto ou desdobramento da personalidade esteja em jogo, estabelecendo com decisão a prioridade a ser dada à pessoa humana, que é o valor fundamental do ordenamento, e está na base de uma série (aberta) de situações existenciais, nas quais se traduz a sua incessantemente mutável exigência de tutela.

11. Para que a pessoa humana refugiada exerça com plenitude os direitos inerentes à sua cidadania universal, é necessário que deixe a invisibilidade. Se por um lado, a simples documentação do indivíduo, dando-lhe condições de residência e trabalho no país, não é suficiente para a integração, por outro lado é condição sine qua non para o exercício de direitos, que só assim se tornam potencialmente efetivos.

12. O desrespeito à proteção dos direitos humanos do refugiado pode redundar em responsabilidade internacional perante os órgãos internacionais de tutela da pessoa humana, tal como a Comissão e a Corte Interamericana de Direitos Humanos.

\section{Referências}

ACNUR. Resolução Normativa $n^{\circ}$ 06, de 26 de maio de 1999. Disponível em <http://www.acnur.org/biblioteca/ pdf/0804.pdf $>$. Acesso em: 19 out. 2008.

ACNUR. XIV Cumbre Iberoamericana: observaciones y recomendaciones del ACNUR. Montevidéu, 4/5 nov. 2006. Disponível em: <http://www.acnur.org/biblioteca/ pdf/4584.pdf $>$. Acesso em: 26 set. 2008.

ANDRADE, José H. Fischel. Direito internacional dos refugiados: evolução histórica (1921-1952). Rio de Janeiro: Renovar, 1996.

BARBOSA, Luciano Pestana; HORA, José Roberto Sagrado da. A Polícia Federal e a proteção internacional dos refugiados. 2006. TCC (Monografia) Curso Superior de Polícia. Brasília, 2006.
BARRETO, Luiz Paulo Teles Ferreira. A política de refúgio no Brasil contemporâneo. In: BOUCAULT, Carlos Eduardo de Abreu; MALATIAN, Teresa. Políticas migratórias: fronteiras dos direitos humanos no século XXI. Rio de Janeiro: Renovar, 2003. p. 63-72.

BOBBIO, Norberto. A Era dos Direitos. Trad. Carlos Nelson Coutinho. Rio de Janeiro: Campus, 1992.

CANOTILHO, J. J. Gomes. Direito constitucional e teoria da constituição. Coimbra: Almedina, 1999.

COMPARATO, F. K. Prefácio. In: RAMOS, André de Carvalho. Teoria geral dos direitos humanos. Rio de Janeiro: Renovar, 2005.

DE CUPIS, Adriano. Os direitos da personalidade. Lisboa: Livraria Morais Editora, 1993.

DONELA, Danilo. Os direitos da personalidade no novo Código Civil. In: TEPEDINO, Gustavo (Coord.). A parte geral do Novo Código Civil: estudos na perspectiva civilconstitucional. Rio de Janeiro: Renovar, 2003.

FEATHERSTONE, Mike. Cultura de consumo e pósmodernismo. São Paulo: Studio Nobel, 1995.

GARCIA, Márcio Pereira Pinto. Refugiado: o dever de solidariedade. In: ARAUJO, Nadia de; ALMEIDA, Guilherme Assis de. $O$ Direito Internacional dos Refugiados: uma perspectiva brasileira. Rio de Janeiro: Renovar, ano- 2001. p. 147-154.

GIL-BAZO, María-Teresa. Refugee protection under international human rights law: maintaining the difference while enjoying equal Treatment. In: SARMENTO, Daniel; IKAWA, Daniela; PIOVESAN, Flávia (Coord.). Igualdade, diferença e direitos humanos. Rio de Janeiro: Lumen Juris, 2008. p. 809-827.

GOFFREDO, Gustavo Sénéchal de. Princípios de política externa como instrumento de democratização da sociedade. In: PEIXINHO, Manoel Messias; GUERRA, Isabella Franco; NASCIMENTO FILHO, Firly (Org.). Os Princípios da Constituição de 1988. Rio de Janeiro: Lumen Juris, 2001. p. 191-206.

GOYARD-FABRE, Simone. Os fundamentos da ordem jurídica. São Paulo: M. Fontes. 2002.

GRAU, Eros Roberto. A ordem econômica na Constituição de 1988. São Paulo: Malheiros. 2003.

HESSE, Konrad. A força normativa da Constituição. Porto Alegre: S. Fabris, 1991. 
JAYME, Erik. O direito internacional privado do novo milênio: a proteção da pessoa humana face à globalização. Cadernos do Programa de Pós-Graduação em Direito PPGDir/UFRGS, Porto Alegre, v. 1, n. 1, mar. 2003.

JUBILUT, Liliana Lyra. O direito internacional dos refugiados e sua aplicação no ordenamento jurídico brasileiro. São Paulo: Método, 2007.

MARINUCCI, Roberto; MILESI, Rosita. Migrantes e refugiados: por uma cidadania universal. Refúgios, migrações e cidadania. Caderno de Debates, Brasília, n. 1, p. 53-80, jun. 2006.

MELLO, Celso D. Albuquerque. Curso de direito internacional público. 15. ed. Rio de Janeiro: Renovar, 2004. v. 2.

MELO, Carolina de Campos. Revisitando o conceito de refúgio: perspectivas para um patriotismo constitucional. In: ARAUJO, Nadia de; ALMEIDA, Guilherme Assis de. $O$ direito internacional dos refugiados: uma perspectiva brasileira. Rio de Janeiro: Renovar, 2001.

MILESI, Rosita. Dia mundial do refugiado 2008: o desafio das políticas públicas. Adital: notícias da América Latina e Caribe, 19 jun. 2008. Disponível em: <http://www. adital.org.br/site/noticia. asp?lang $=\mathrm{PT} \& \operatorname{cod}=33572>$. Acesso em: 26 set. 2008.

MILESI, Rosita; LACERDA, Rosane (Org.). Políticas públicas para as migrações internacionais: migrantes $\mathrm{e}$ refugiados. 2. ed. Brasília: ACNUR/IMDH/CDHM, 2007.

MORAES, Maria Celina Bodin. O princípio da solidariedade. In: PEIXINHO, Manoel Messias; GUERRA, Isabella Franco; NASCIMENTO FILHO, Firly (Org.). Os princípios da Constituição de 1988. Rio de Janeiro: Lumen Júris, 2001.

OFICINA DEL ALTO COMISIONADO DE LAS NACIONES UNIDAS PARA REFUGIADOS. Documento para discusion: el racismo, la discriminación racial, la xenofoia y la intolerância conexa hacia los refugiados, 28 fev. 2000. Disponível em: <http://www.oas.org/dil/xxxiv/ Documentos/Juan\%20Carlos\%20Murillo/JCMurillo. racismo,\%20intolerancia,\%20xenofobia.pdf $>$. Acesso em: 26 set. 2008.

ORGANIZAÇÃO DOS ESTADOS AMERICANOS. Corte Interamericana de Direitos Humanos, Caso das Irmãs Serrano Cruz vs. El Salvador, Sentença de 23 de novembro de 2004. Disponível em: $<$ www.oas.org.>. Acesso em: 19 jun. 2008.

PERLINGIERI, Pietro. Perfis do direito civil: introdução ao direito civil constitucional. Rio de Janeiro: Renovar, 1999.
PIOVESAN, Flávia. Direitos humanos $e$ o direito constitucional internacional. 9. ed. São Paulo: Saraiva, 2008.

PIOVESAN, Flávia. O direito de asilo e a proteção internacional dos refugiados. In: ARAUJO, Nadia de; ALMEIDA, Guilherme Assis de. O Direito Internacional dos Refugiados: uma perspectiva brasileira. Rio de Janeiro: Renovar, 2001. p. 27-64.

POGREBINSCHI, Thamy. O direito de asilo e a Constituinte de 1987-88. In: ARAUJO, Nadia de; ALMEIDA, Guilherme Assis de (Org.). O direito internacional dos refugiados: uma perspectiva brasileira. Rio de Janeiro: Renovar, 2001. p. 319-342.

PULIDO, María Claudia; BLANCHARD, Marisol. La comision interamericana de derechos humanos $y$ sus mecanismos de proteccion aplicados a la situacion de los refugiados, apátridas y solicitantes de asilo, [2007]. Disponível em: <http://www.oas.org/dil/xxxiv/ Documentos/Juan\%20Carlos\%20Murillo/JCMurillo.co misi\%F3ninteramericanayrefugiados.pdf $>$. Acesso em: 26 set. 2008.

RAMOS, André de Carvalho. Direitos dos estrangeiros no Brasil: a imigração, direito de ingresso e os direitos dos estrangeiros em situação irregular. In: SARMENTO, Daniel; IKAWA, Daniela; PIOVESAN, Flávia (Coord.) Igualdade, diferenças e direitos humanos. Rio de Janeiro: Lumen Júris, 2008. p. 721-746.

RAMOS, André de Carvalho. Teoria geral dos direitos humanos. Rio de Janeiro: Renovar, 2005.

SAN JUAN, César Walter. El asilo y la protección de los refugiados en América Latina: análisis crítico del dualismo "asilo-refugio" a la luz del derecho internacional de los derechos humanos, 2005. Disponível em: <http://www. acnur.org/paginas/index.php?id_pag=3468 $>$. Acesso em: 26 set. 2008.

SCHIER, Paulo Ricardo. Filtragem constitucional: construindo uma nova dogmática jurídica. Porto Alegre: S. A. Fabris, 1999.

SILVA, José Afonso da. Aplicabilidade das normas constitucionais. São Paulo: Revista dos Tribunais, 1998.

SILVA, José Afonso da. Curso de direito constitucional positivo. 11. ed. São Paulo: Malheiros, 1996.

TRINDADE, Antônio Augusto Cançado. Teoria do ordenamento jurídico. 5. ed.. Trad. Maria Celeste Cordeiro Leito dos Santos. Brasília: Universidade de Brasília, 1996. 
TRINDADE, Antônio Augusto Cançado. Tratado de direito internacional dos direitos humanos. 2. ed. Porto Alegre: Safe, 2003.

VARESE, Luis. Três elos da corrente dos direitos humanos. Refúgios, migrações e cidadania. Caderno de Debates, Brasília, n. 1, p. 7-12, jun. 2006.
WARAT, Luis Alberto. Introdução geral ao direito: a epistemologia jurídica da modernidade. Porto Alegre: S. A. Fabris, 1995. v. 2 